\title{
PENGGUNAAN MEDIA BONEKA TANGAN DALAM MENINGKATKAN KETERAMPILAN MENYIMAK SISWA PADA MATAPELAJARAN SEJARAH KEBUDAYAAN ISLAM
}

\author{
Aqodiah \\ Dosen Fakultas Agama Islam Universitas Muhammadiyah Mataram \\ Email: aqodiiah@gmail.com
}

\begin{abstract}
Abstrak
Penggunaan media pembelajaran bagi siswa usia madrasah ibtidaiyah di rasa sangat tepat, karena sesuai dengan tahap perkembangannya mereka masih berada pada tahap operasiona kongkret, dalam hal ini peneliti menggunakan media boneka tangan dalam meningkatkan keterampilan menyimak anak pada mata pelajaran Sejarah Kebudayaan Islam (SKI). Pendekatan penelitian ini adalah kuantitatif dengan jenis deskriptif. Jenis penelitian adalah penelitian tindakan kelas. Penelitian ini terdiri dari variabel terikat yaitu keterampilan menyimak pada mata pelajaran (SKI) dan variabel bebas yaitu media boneka tangan. Populasi penelitian ini adalah siswa kelas V A MIN 2 Mataram yang berjumlah 38 siswa.instrumen yang digunakan dalam penelitian ini adalah observasi, tes dan dokumentasi. Tehnik analisis data yang digunakan yaitu, kuantitatif deskriptif juga reduksi data, pemaparan data, pembahasan, dan penarikan kesimpulan. Untuk pengecekan keabsahan data penelitian menggunakan ketekunan pengamatan dan triangulasi. Hasil penelitian menunjukkan ada pengaruh penggunaan media boneka tangan dalam meningkatkan keterampilan menyimak pada mata pelajaran sejarah kebudayaan Islam (SKI) siswa kelas V MIN 2 Mataram. Hal ini ditunjukkan malalui hasil uji tes tulis siswa di siklus I yaitu 71,1 meningkat menjadi 75,34 pada siklus II.
\end{abstract}

Kata kunci: keterampilan menyimak pada pelajaran sejarah kebudayaan Islam

\section{A. LATAR BELAKANG MASALAH}

Pendidikan menurut Brubacher (Modern philosophies of Education), merupakan suatu proses timbal-balik dari tiap pribadi manusia dalam penyesuaian dirinya dengan alam, teman, dan alam semesta. ${ }^{1}$ Menurut Dahama \& Bhatnagar yang dikutip dalam buku Rulam Ahmadi, pendidikan merupakan proses untuk membawa perubahan yang diinginkan dalam perilaku manusia. Pendidikan dapat

11 Rulam Ahmadi, Penagntar Pendidikan (Asas E Filsafat Pendidikan), (Yogyakarta: Ar-Ruzz Media), 33

\begin{tabular}{|c|c|c|c|c|c|} 
Jurnal & Volume & Nomor & Halaman & Mataram & ISSN \\
Ibtida'iy & 04 & 1 & $1-97$ & April 2019 & $2501-504 \mathrm{X}$
\end{tabular}


juga didefinisikan sebagai proses perolehan pengetahuan dan kebiasaan-kebiasaan melalui pembelajaran atau studi. ${ }^{2}$

Pendidikan Agama merupakan salah satu mata pelajaran yang paling diutamakan, lebih khusus di Madrasah, secara umum pendidikan Agama adalah upaya untuk menjadikan manusia mampu untuk mewujudkan tujuan penciptaannya. Manusia diciptakan agar mereka mengetahui hakikat Tuhannya, mengesakan, memurnikan ibadah kepada Tuhannya, dan mau menghambakan diri dengan menjalankan seluruh perintah dan menjauhi semua larangannya.

Madrasah ibtidaiyah adalah sebuah lembaga pendidikan awal untuk mempelajari ilmu tentang Agama, berbeda dengan sekolah dasar pada umumnya. Salah satu mata pelajaran yang wajib ada pada jenjang pendidikan madrasah ibtidaiyah adalah mata pelajaran sejarah kebudayaan Islam. Pelajaran Sejarah Kebudayaan Islam diberikan dengan tujuan untuk mengembangkan sikap positif peserta didik dalam memahami dan dapat mengetahui dengan benar sejarah Islam secara keseluruhan.

Menyimak pada mata pelajaran sejarah kebudayaan Islam tidak dipelajari secara khusus dalam bab tertentu seperti halnya pada mata pelajaran bahasa Indonesia. Belajar sejarah atau kisah merupakan suatu hal yang sangat penting untuk dipelajari di sekolah-sekolah khususnya di Madrasah Ibtidaiyah. Menyimak dan sejarah masing-masing memiliki keterkaitan, karena ketika mempelajari sejarah maka dibutuhnya kemampuan menyimak untuk dapat memahaminya. Karena khususnya di dalam sejarah kebudayaan Islam membahas tentang bagaimana kehidupan Islam dari sejak Rasulullah masih hidup memimpin kaum muslimin serta ketika setelah beliau wafat dan digantikan oleh khulafa ArRasyidin yang empat kemudian digantikan oleh khalifah-khalifah setelahnya.

Faktanya anak-anak saat ini cenderung sangat mudah bosan ketika diberikan pelajaran yang berkaitan dengan sejarah, karena ketika kita belajar tentang sejarah identik dengan seorang guru yang hanya menggunakan metode ceramah dalam menyampaikan pelajaran, oleh karena itu anak-anak cenderung tidak mau mendengarkan apa yang di sampaikan. seperti halnya, mereka bermain

\section{Ibid, 35}


bersama dengan temannya, menyibukkan diri dengan hal-hal yang tidak bermanfaat,dan sebagainya. Sehingga materi atau KD (kompetensi dasar) yang di harapkan akan diraih oleh siswa akan tersa sulit, sebagaimana yang terjadi di MIN 2 Mataram.

Penggunaan media sangat penting dalam kegiatan pembelajaran. Media merupakan alat bantu yang dapat di gunakan guru untuk menyampaikan suatu materi agar siswa lebih mudah dalam memahami isi atau pesan yang ada pada suatu mata pelajaran. Penggunaan media pembelajaran bagi siswa usia madrasah ibtidaiyah di rasa sangat tepat, karena sesuai dengan tahap perkembangannya mereka masih berada pada tahap operasional kongkret ${ }^{3}$, maksudnya anak akan belajar lebih baik apabila menghadapi lingkungan dengan baik dan sesuai dengan realitas. ${ }^{4}$ Menurut Gerlach secara umum media itu meliputi orang, bahan, peralatan, atau kegiatan yang menciptakan kondisi yang memungkinkan siswa memperoleh pengetahuan, keterampilan, dan sikap. ${ }^{5}$ Rossi dan Breidle yang dikutip dalam Wina Sanjaya, menyatakan bahwa media pembelajaran adalah seluruh alat dan bahan yang dapat dipakai untuk tujuan pendidikan, seperti radio, televise, buku, Koran, majalah, dan sebagainya. ${ }^{6}$

Pernyataan tersebut didukung oleh survei yang dilakukan oleh Vernon A.Magnesen dalam mengenai penggunaan waktu berkomunikasi pada keempat keterampilan berbahasa dengan hasil minyimak (dilihat dan di dengar) 50\%, dibaca $10 \%$, didengar 20\%, dan lihat 30\%, dikatakan $70 \%$, dilakukan dan dikatakan $90 \%^{7}$. Selain itu, hasil dari penelitian Brown (Henry Guntur Tarigan,) menyatakan bahwa $70 \%$ dari jam bangun orang dewasa dipergunakan untuk berkomunikasi baik secara santai maupun serius dan $45 \%$ dari waktu tersebut digunakan untuk menyimak. Dari kedua penelitian tersebut dapat dilihat bahwa waktu yang digunakan untuk menyimak lebih banyak dibandingkan waktu yang digunakan untuk berbicara, membaca, dan menulis. Oleh karena itu, pembelajaran

\footnotetext{
${ }^{3}$ Andi Prastowo, Pengembangan Bahan Ajar Tematik, (Jakarta: Kencana.2014), 31-34.

4 Ratna Yudhawati \& Dany Haryanto. Teori-Teori Dasar Psikologi Pendidikan, (Jakarta: PT. Prestasi Pustakarya.2011), 70

5 Wina Sanjaya, Perencanaan Dan Desain Sistem Pembelajaran, (Jakarta. PT Fajar Interpratama Mandiri. 2013) 204-205

6 Ibid 204-205

7 Zainal Aqib, Model-Model, Media, Dan Strategi Pembelajaran Kontekstual (Inovatif), (Bandung: Yrama Widya.2016). 48 
menyimak di Madrasah perlu diberikan perhatian agar seimbang dengan presentase menyimak dalam kegiatan sehari-hari. ${ }^{8}$

Berdasarkan observasi awal terlihat bahwa guru hanya menggunakan metode ceramah pada pembelajaran SKI. Dalam pembelajaran dengan menggunakan metode ceramah, dan menggunakan media teks bacaan atau LKS, sehingga guru lebih berperan dibandingkan siswa. Siswa hanya mendengarkan materi yang disampaikan oleh guru dan biasanya dilanjutkan dengan mengerjakan soal. Hal tersebut mengakibatkan siswa cenderung pasif dalam mengikuti kegiatan pembelajaran. ${ }^{9}$ Hal tersebut menyebabkan siswa memiliki daya menyimak yang kurang baik atau penyimak jelek (poor listener). ${ }^{10}$

\section{B. METODE PENELITIAN}

\section{Jenis penelitian}

Adapun jenis penelitian yang digunakan dalam penelitian ini adalah penelitian tindakan kelas (PTK). Istilah PTK dalam bahasa Inggris adalah Classroom Action Research (CAR). Dari namanya sudah menunjukkan isi isi yang terkandung didalamnya, yaitu sebuah penelitian yang di lakukan di dalam kelas. $^{11}$

\section{Sasaran penelitian}

Sasaran atau objek penelitian ini adalah peningkatan keterampilan menyimak siswa pada mata pelajaran Sejarah Kebudayaan Islam dengan menggunakan media boneka tangan kelas V MIN 2 Mataram tahun pelajaran 2017/2018. Target yang diharapkan adalah meningkatnya keterampilan menyimak dalam belajar Sejarah Kebudayaan Islam.

\section{Sistematika penelitian}

Penelitian ini direncanakan dalam sisklus-siklus dengan masing-masing siklus terdiri dari perencanaan, pelaksanaan, pengamatan, dan refleksi. Keempat tahap tersebut membentuk sebuah siklus yang berurutan dan selanjutnya kembali ke langkah semula dan seterusnya. Arikunto secara garis besar terdapat 4 tahapan

8 Henry Guntur Tarigan, Menyimak (sebagai suatu keterampilan berbahasa). (Bandung. CV. Angkasa.2013) , 132

9 Observasi awal

10 Henry Guntur Tarigan, Menyimak (sebagai suatu keterampilan berbahasa). (Bandung. CV. Angkasa.2013), 141

11 Arikunto\& Suharsimi. Penelitian Tindakan Kelas.( Jakarta: PT. Bumi Aksara.2009), 2

\begin{tabular}{|c|c|c|c|c|c|} 
Jurnal & Volume & Nomor & Halaman & Mataram & ISSN \\
Ibtida'iy & 04 & 1 & $1-97$ & April 2019 & $2501-504 \mathrm{X}$
\end{tabular}


yang lazim dilalui, yaitu (1) perencanaan, (2) pelaksanaan, (3) pengamatan, dan (4) refleksi.

Adapun model dan penjelasan untuk masing-masing tahap adalah sebagai berikut:

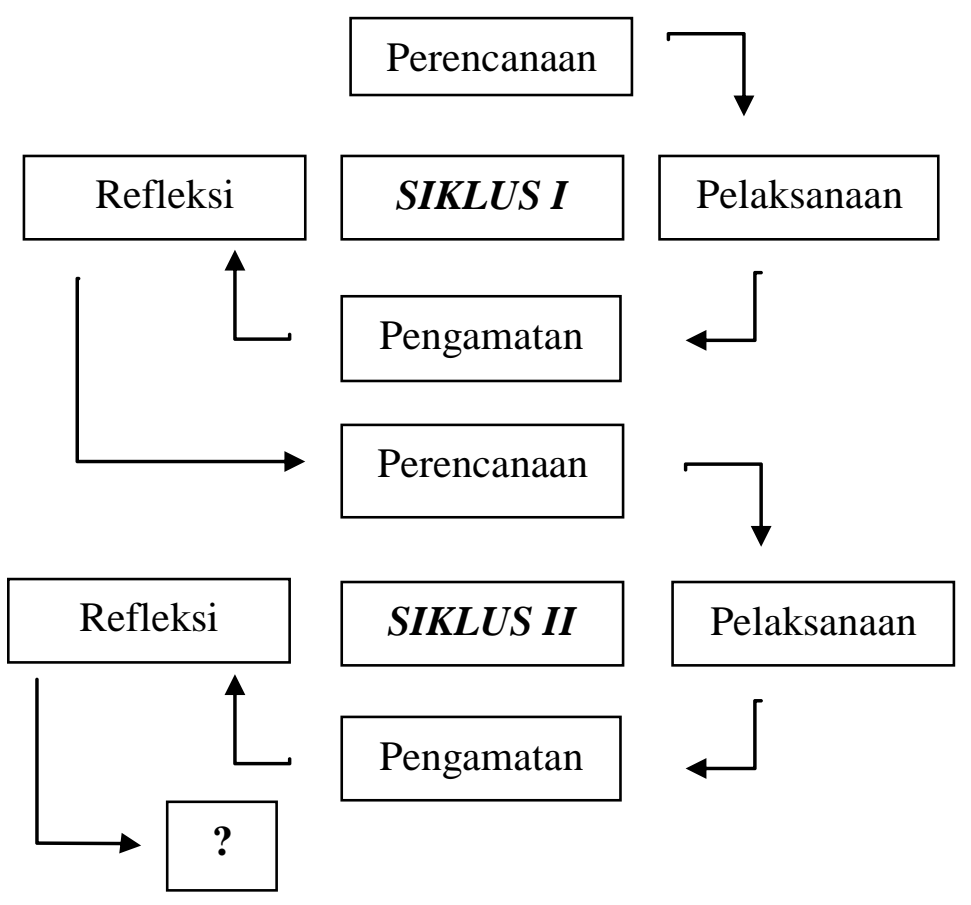

(Arikunto dkk, 2009: 16) ${ }^{12}$

\section{Gambar 3.1 siklus PTK}

\section{a. Prosedur penelitian atau (Langkah-lagkah peneltian)}

\section{1) Siklus 1}

a) Tahap pertama perencanaan tindakan

Pada tahap ini peneliti melakukan fokus peristiwa yang perlu mendapatkan perhatian khusus untuk diamati, kemudian membuat instrumen pengamatan untuk merekam fakta yang terjadi selama tindakan berlansung.

Secara rinci pada tahapan ini terdiri dari kegiatan sebagai berikut:

(1) Membuat skenario pembelajaran

12 Arikunto\& Suharsimi. Penelitian Tindakan Kelas.( Jakarta: PT. Bumi Aksara.2009), 16 
(2) Membuat lembar observasi untuk melihat bagaimana kondisi belajar mengajar yang diperlukan dalam rangka meningkatkan kemampuan siswa.

(3) Membuat alat bantu mengajar yang bertujuan untuk meningkatkan kemampuan siswa.

b) Tahap kedua pelaksanaan

Pada tahap pelaksanaan ini, rencana strategi dan skenario yang telah disusun pada perencanaan tindakan akan diterapkan dalam upaya meningkatkan keterampilan menyimak siswa.

c) Tahap ketiga observasi dan evaluasi

Pada tahap ini, dilakukan observasi terhadap pelaksanaan tindakan dengan menggunakan lembar observasi, dimana pada tahap ini siswa diobservasi oleh observer yaitu peneliti melakukan kerja sama dengan guru bidang studi. Evaluasi dilaksanakan pada tiap akhir siklus dengan tes yang diberikan secara individual selama jam pelajaran berlangsung. Soal yang diberikan berupa soal essay sebanyak 5 butir dengan skor maksimal untuk setiap butir soal adalah 20 dan skor minimalnya adalah 0 .

d) Tahap keempat refleksi

Pada tahap ini, peneliti bersama guru mengkaji hasil pelaksanaan dan yang diperoleh secara rinci dalam pemberian tindakan pada tiap siklus. Hal ini dilakukan dengan melihat data hasil evaluasi yang dicapai siswa. Hal ini digunakan untuk meperbaiki serta menyempurnakan pemberian tindakan perencanaan dan pelaksanaan tindakan pada siklus selanjutnya.Setelah menganalisis hasil belajar dan hasil observasi, guru dapat mengetahui tingkat keberhasilan yang diperoleh oleh siswa, dan untuk selanjutnya dipersiapkan pelaksanaan siklus II apabila pada siklus I ketuntasan belajar belum mencapai target.

\section{2) Siklus II}

Pelaksanaan siklus II ini berdasarkan pada hasil refleksi yang sudah dilaksanakan pada siklus I, dengan pertimbangan hasil obsrvasi dan evaluasi tahapan-tahapan yang sudah tertera pada siklus I dan siklus II juga 
merupakan penyempurnaan dari siklus I dengan tujuan mendapatkan hasil yang lebih baik.

\section{HASIL PENELITIAN DAN PEMBAHASAN}

Pelaksanaan penelitian tindakan kelas ini dilaksanakan dalam 2 (dua) siklus. Penelitian ini dilakukan untuk meningkatkan keterampilan menyimak siswa kelas V MIN 2 Mataram pada pokok bahasan "Kholifah Abbu Bakar" melalui penerapan media boneka tangan. Subjek penelitiannya adalah siswa kelas V MIN 2 Mataram tahun pelajaran 2017/2018 yang berjumlah 38 siswa. Pada penelitian ini, data tentang menyimak siswa diperoleh dari hasil evaluasi yang dilaksanakan tiap akhir siklus, sedangkan data tentang aktivitas siswa dan guru dalam proses pembelajaran di kelas diperoleh dari lembar observasi.

Gambaran umum tentang lokasi penelitian sangatlah diperlukan oleh peneliti untuk mengetahui tentang apa yang diteliti, dan bisa menjadi bahan referensi tambahan dalam melakukan penelitian. Oleh sebab itu peneliti akan memaparkan secara rinci tentang keberadaan MIN 2 Mataram dan keadaannya sebagai lembaga pendidikan islam. Berdasarkan data yang diperoleh melalui observasi, dokumentasi resmi serta wawancara.

\section{Pembahasan tentang pengaruh penggunaan media boneka tangan dalam meningkatkan keterampilan menyimak pada mata pelajaran SKI}

Penelitian tindakan kelas ini dilaksanakan untuk meningkatkan keterampilan menyimak anak pada mata pelajaran SKI pokok bahasan "kholifah Abu Bakar as-Siddiq" dengan menerapkan media boneka tangan. Penelitian ini dilaksanakan dalam dua siklus selama 4 kali pertemuan, masing-masing pertemuan 2x35 menit dan untuk evaluasi akhir siklus adalah 1x35 menit. Dari data hasil penelitian siklus I menunjukkan bahwa nilai rata-rata 70,26 dan skor rata-rata aktivitas belajar siswa adalah 13,25 dengan cukup aktif. Pada siklus I terdapat kekurangan-kekurangan dalam proses pembelajaran misalnya siswa enggan mengajukan pertanyaan kepada guru meskipun ada materi yang belum dipahami, selain itu interaksi siswa dalam kelompok masih kurang, kegiatan diskusi hanya didominasi oleh siswa yang pandai saja, sehingga diskusi kelompok kurang berjalan sesuai dengan yang diharapkan. Pengaturan waktu yang dilakukan guru belum optimal baik pada saat diskusi dan presentasi, siswa masih belum bisa 
menjawab pertanyaan yang dilontarkan oleh guru/peneliti. Guru/peneliti juga belum tegas dalam mengontrol maupun memotivasi siswa sehingga penguatan dari guru /peneliti masih kurang. Guru/peneliti masih kurang memperhatikan intonansi sehingga menyebabkan siswa tidak tertarik dengan apa yang di sampaikan guru/peneliti dan cenderung bosan serta mengantuk, sehingga ini semua dapat berpengaruh terhadap hasil tes essay untuk mengetahui kempuan menyimak siswa. Oleh karena itu untuk mengatasi hal tersebut maka diadakan perbaikan pada siklus II dengan perbaikan ini diharapkan hasil yang diperoleh dapat mengalami perbaikan dan peningkatan.

Proses pembelajaran siklus II dilaksanakan seperti pada siklus I, pada siklus II dilakukan perbaikan-perbaikan berdasarkan kekurangan-kekurangan yang ditemukan pada siklus I. Sebelum membahas materi baru terlebih dahulu guru/peneliti menjelaskan tujuan pembelajaran yang ingin dicapai, menjelaskan kemudian dilanjutkan dengan kegiatan diskusi. Dalam kegiatan diskusi guru/penenliti lebih intens lagi memberikan bimbingan kepada masing-masing anggota kelompok untuk saling membantu antar kelompok sehingga siswa yang sudah mengerti dapat menjelaskan ketemannya yang belum mengerti. Guru/penelii juga lebih mendekati siswa dan aktif menanyakan kesulitan yang sekiranya dihadapi oleh siswa, sehingga siswa tidak malu bertanya jika ada halhal yang belum dipahami. Guru/peneliti juga lebih bisa mengendalikan kelas proses pembelajaran tidak terganggu oleh tingkah laku siswa yang sulit diatur, dalam kegiatan mengisahkan tentang kisah sahabat guru/peneliti juga sudah lebih bisa mengontrol dan mengkondisikan jalannya proses menyimak, seperti halnya memperhatikan intonansi. Sehingga pada isklis II ini siswa yang pada siklus I masih malu bertanya menjadi berani untuk bertanya, serta siswa yang tidak bisa menjawab pertanyaan guru sudah mulai bisa menjawab pertanyaan yang dilontarkan guru, serta terlihat dari hasil tes essay yang di berikan sudah tampak lebih baik sehingga guru dapat melihat bahwasannya kemempuan menyimak anak semakin meningkat dari yang sebelumnya.

Berdasarkan hasil observasi aktivitas belajar siswa siklus II diketahui bahwa skor aktivitas belajar siswa mengalami penigkatan, yaitu dari 13,25 menjadi 14,65 dengan aktif. Pada evaluasi siklus II diperoleh rata-rata nilai siswa sebesar 75,34 
mangalami peningkatan dari siklus sebelumnya yaitu 70,26 hal ini terjadi karena guru/peneliti melakukan perbaikan terhadap kekurangan-kekurangan yang terdapat pada siklus I. Kerjasama siswa mengalami peningkatan dari siklus sebelumnya meskipun masih ada beberapa siswa yang kurang aktif dalam diskusi.

Peningkatan taraf menyimak siswa yang di lihat dari hasil tes atau belajar yang siswa pada setiap siklusnya, serta tidak terlepas dari media boneka tangan yang digunakan. Senada dengan yang disampaikan Tarigan bahwa untuk meningkatkan menyimak konsentratif pada anak menggunakan alternatif gambargambar atau media yang lain yang sesuai dengan cerita atau kisah yang di sampaikan. ${ }^{13}$ Hasil ini sejalan dengan penelitian Diah Ayu Widowati bahwa dalam hasil penelitiannya penerapan media boneka tangan terhadap keterampilan menyimak cerita dapat meningkatkan hasil belajar siswa baik dari segi kognitif maupun afektif. ${ }^{14}$

Penggunaan media boneka tangan dalam proses pembelajaran dapat menarik perhatian siswa, sehingga menumbuhkan motivasi belajar dalam diri siswa. Penggunaan media boneka tangan dalam proses pembelajaran juga membuat pesan atau isi cerita atau kisah yang disampaikan oleh guru secara lisan menjadi lebih konkret dan lebih jelas, sehingga mudah dipahami oleh siswa.

Menurut Bachtiar Bachri boneka merupakan representasi wujud banyak obyek yang sangat disukai oleh anak dan memiliki daya tarik yang sangat kuat pada anak. Daya tarik yang sangat kuat dari boneka termasuk media boneka tangan dapat menumbuhkan motivasi belajar pada diri siswa. Hal tersebut sesuai dengan pemaparan Sudjana \& Rivai (Azhar Arsyad) yang menyatakan bahwa media pembelajaran dapat menarik perhatian siswa, sehingga menumbuhkan motivasi belajar dalam diri siswa. ${ }^{15}$

Penggunaan media boneka tangan dapat membuat siswa memahami isi kisah yang disampaikan oleh guru/peneliti, sehingga keterampilan menyimak siswa

${ }^{13}$ Henry Guntur Tarigan, Menyimak (sebagai suatu keterampilan berbahasa). (Bandung. CV. Angkasa.2013) , 165

14 Diah Ayu Widiowati, Pengaruh Penggunaan Media Boneka Tangan Terhadap Keterampilan Menyimak Cerita Siswa Kelas II B SD Negeri Margoyasan Yogyakarta, Fakultas Ilmu Pendidikan, Universitas Negeri Yogyakarta.2016

15 R Ibrahim \& Nana Sudjana, perencanaan pengajaran. (Jakarta: PT Rineka Cipta,2003), 114119

\begin{tabular}{|c|c|c|c|c|c|} 
Jurnal & Volume & Nomor & Halaman & Mataram & ISSN \\
Ibtida'iy & 04 & 1 & $1-97$ & April 2019 & $2501-504 x$
\end{tabular}


kelas V MIN 2 Mataram menjadi lebih baik. Karena untuk memahami isi sebuah kisah dibutuhkan proses mendengarkan dengan penuh pemahaman dan perhatian, agar pesan atau informasi yang terkandung dalam kisah tersebut dapat di terima dengan baik dan dapat di aplikasikan dalam kehidupan sehari hari, ini sesuai dengan pernyataan Russel \& Russell mengenai makna menyimak. Hal tersebut dapat dilihat dari nilai rata rata siswa setelah menggunakan media boneka tangan. Sesuai dengan yang disampaikan Tarigan dalam bukunya, bahwa untuk mengetahui kemampuan menyimak anak memperhatikan guru/peneliti di depan kelas dapat diketahui dengan memberikan tugas-tugas atau tugas rumah yang lainnya. ${ }^{16}$ Serta sejalan dengan penelitian yang dilakukan oleh prof. Brown tahun 1951 di Universitas of Minnesota Amerika Serikat dia menggunakan uji tulis untuk mengetahui taraf pemahaman menyimak mahasiswanya ketika belajar. ${ }^{17}$

Oleh karena itu, secara keseluruhan hasil dari penelitian inı menunjukkan bahwa penerapan media boneka tanagn dapat meningkatkan keterampilan menyimak siswa pada mata pelajaran SKI siswa kelas V MIN 2 Mataram.

\section{E. PENUTUP}

\section{Kesimpulan}

Penggunaan media boneka tangan dapat meningkatkan keterampilan menyimak anak pada mata pelajaran SKI pada pokok bahasan "Kholifah Abu Bakar as-Siddiq" siswa kelas V MIN 2 Mataram tahun ajaran 2017/2018. Hal ini terbukti dengan terjadinya peningkatan nilai rata-rata hasil belajar siswa pada siklus I sebesar 71,1 meningkat menjadi sebesar 75,34 pada siklus II dengan ketuntasan belajar klasikal siswa dari $63,15 \%$ pada siklus I meningkat sebesar $86,84 \%$ pada siklus II. Aktivitas belajar siswa juga meningkat dari siklus I pada kategori kurang aktif menjadi cukup aktif pada siklus II.

\section{F. DAFTAR PUSTAKA}

\footnotetext{
16 Henry Guntur Tarigan, Menyimak (sebagai suatu keterampilan berbahasa). (Bandung. CV. Angkasa.2013) , 157

17 Henry Guntur Tarigan, Menyimak (sebagai suatu keterampilan berbahasa). (Bandung. CV. Angkasa.2013) , 141

92

\begin{tabular}{|c|c|c|c|c|c|} 
Jurnal & Volume & Nomor & Halaman & Mataram & ISSN \\
Ibtida'iy & 04 & 1 & $1-97$ & April 2019 & $2501-504 X$
\end{tabular}
}


Abbas Saleh . (2006) Pembelajaran Bahasa Indonesia yang Efektif di Sekolah Dasar. Jakarta: Departemen Pendidikan Nasional Direktorat Jendral Pendidikan Tinggi Direktorat Ketenagaan.

Ahmadi Rulam, Penagntar Pendidikan (Asas \& Filsafat Pendidikan), Yogyakarta: Ar-Ruzz Media.

Amin Samsul Munir. (2015) Sejarah Peradaban Islam,Jakarta: Remaja Rosdakarya.

Aqib Zainal, (2016) Model-Model, Media, Dan Strategi Pembelajaran Kontekstual (Inovatif), Bandung: Yrama Widya.

Cakra Ki Heru. (2012) Mendongeng dengan Mata Hati. Surabaya: Mumtaz Media.

Daryanto. (2013) Media Pembelajaran. Yogyakarta, Gava Media.

Diah Ayu Widiowati, Pengaruh Penggunaan Media Boneka Tangan Terhadap Keterampilan Menyimak Cerita Siswa Kelas II B SD Negeri Margoyasan Yogyakarta, Fakultas Ilmu Pendidikan, Universitas Negeri Yogyakarta.2016.

Jurnal Pendidikan Agama Islam, Vol. XII, No. 1. Juni 2015.

Nana Sudjana dan Ahmad Rivai. 2002. Media Pengajaran. Bandung: Sinar Baru Algensindo.

Nurkancana dan Sunartana.1990. Evaluasi Hasil Belajar. Surabaya: Usaha Nasional.

PERMENDIKNAS 2006 tentang SI dan SKL,Jakarta: Sinar Grafika.

Prastowo Andi, (2014) Pengembangan Bahan Ajar Tematik, Jakarta: Kencana.

Ngalim Purwanto, (2008) Prinsip-Prinsip dan Teknik Evaluasi Pengajaran Bangung: Remaja Rosdakarya.

.Ratna Yudhawati \& Dany Haryanto. (2011) Teori-Teori Dasar Psikologi Pendidikan, Jakarta: PT. Prestasi Pustakarya. 